\title{
PERCOBAAN PRODUKSI BIOGAS DARI KOTORAN SAPI DAN KOTORAN AYAM DENGAN PENAMBAHAN ENZIM PAPAIN
}

\author{
Zulfikar Ali As, Hardiono, Syarifudin A. \\ Poltekkes Kemenkes Banjarmasin Jurusan Kesehatan Lingkungan Banjarbaru \\ Jl. H. Mistar Cokrokusumo No. 1A Kota Banjarbaru \\ zulyan03@gmail.com
}

\begin{abstract}
Production of Biogas from Cow Manure and Chicken Manure with Addition of Papain. Farms not only contribute positively to meet the demands of protein and increase incomes but also have a negative impact on the environment due to their wastes, especially manure. Biogas produced from the anaerobic decomposition of organic waste is a solution of manure utilization to be a fuel which is cheap and environmentally friendly. To accelerate the production of biogas it is needed a proteoloitik enzyme from papaya, which is called papain. This study aims to calculate the production of biogas from cow manure and chicken manure with addition of papain. The experiments were conducted in the digester made from plastic drums and observed for 30 days. The results showed that the papain influenced of production acceleration of biogas from cow manure. Comparison of biogas production in a week from cow manure: cow manure + 2 kgs of papaya pieces: cow manure +4 kgs of papaya pieces are 202.7 liters: 263 liters: 332.3 liters. Cow manure did not need other ingredients except water with ratio $1: 1 \frac{1}{2}$. Chicken manure had not been able to produce biogas because their $\mathrm{CN}$ ratio was not eligible, although the chaff had been added to increase the carbon content. Biogas from cow manure with addition of papain can be applied on a wider scale, while biogas from chicken manure requires other ingredients that biodegrade easier to add C content in the mixture.
\end{abstract}

Keywords : biogas; cow manure; chicken manure; papain

\begin{abstract}
ABSTRAK
Percobaan Produksi Biogas dari Kotoran Sapi dan Kotoran Ayam dengan Penambahan Enzim Papain. Peternakan selain berkontribusi positif untuk memenuhi kebutuhan protein dan meningkatkan pendapatan masyarakat juga berdampak negatif bagi lingkungan akibat limbahnya terutama kotoran. Biogas merupakan solusi pemanfaatan kotoran menjadi bahan bakar alternatif yang murah dan ramah lingkungan. Percobaan ini bertujuan mengetahui potensi biogas dari kotoran sapi dan kotoran ayam dan efek penambahan enzim papain terhadap percepatan produksi biogas. Hipotesa penelitian adalah kotoran sapi maupun kotoran ayam dapat menghasilkan biogas, dan enzim papain mampu mempercepat produksi biogas. Percobaan dilakukan dalam tiga buah digester yang mewakili tiga perlakuan bahan, yaitu kotoran murni, kotoran ditambah $2 \mathrm{~kg}$ potongan buah pepaya, dan kotoran ditambah $4 \mathrm{~kg}$ potongan buah pepaya. Hasil observasi dianalisis secara deskriptif dengan cara membandingkan produksi biogas dari masing-masing perlakuan. Hasil percobaan menunjukkan kotoran sapi dapat menghasilkan biogas namun kotoran ayam tidak. Enzim papain terbukti mampu mempercepat produksi biogas dalam satu minggu pertama dengan perbandingan volume produksi: 202,7 liter : 263 liter : 332,3 liter untuk masing-masing variasi perlakuan. Produksi biogas dari kotoran sapi dengan bantuan enzim papain terbukti lebih efektif. Kotoran ayam yang tidak menghasilkan biogas disebabkan rasio $\mathrm{CN}$ yang terlalu rendah. Penambahan sekam untuk meningkatan CN melalui penambahan unsur karbon belum efektif. Untuk penelitian selanjutnya disarankan bahan pencampur kotoran ayam adalah bahan organik yang lebih mudah terurai.
\end{abstract}

Kata kunci : biogas; kotoran ayam; kotoran sapi; papain

\section{PENDAHULUAN}

Industri peternakan di samping memberikan kontribusi besar untuk pemenuhan kebutuhan protein, peningkatan pendapatan masyarakat dan devisa negara, juga berdampak negatif bagi lingkungan akibat limbah yang dihasilkannya. Kotoran sebagai bagian terbesar dari limbah peternakan jika masuk ke lingkungan dapat menyebabkan gangguan estetika, menjadi tempat per- 
kembangbiakan vektor dan parasit serta meningkatkan kandungan kimia organik. Industri peternakan juga mengemisikan $\mathrm{CH}_{4}$ yang memiliki potensi panas 70 kali dibandingkan $\mathrm{CO}_{2}$, dan menjadi salah satu aktor utama pemanasan global. (1).

Potensi panas $\mathrm{CH}_{4}$ dari kotoran dapat dimanfaatkan untuk bahan bakar ramah lingkungan yang dikenal dengan istilah biogas. Didominasi oleh $60 \%$ gas methan dan $40 \%$ gas $\mathrm{CO}_{2}$, biogas dapat dibuat dengan teknologi sederhana melalui proses fermentasi bahan-bahan organik yang berasal dari limbah rumah tangga dan kotoran hewan (sapi, babi, ayam) oleh bakteri anaerob (2). Dengan demikian pemanfaatan biogas tidak hanya mengurangi dampak negatif kotoran ternak terhadap lingkungan tetapi juga memberikan solusi bahan bakar yang saat ini ketersediannya semakin terbatas (3).

Pemanfaatan kotoran ternak untuk produksi biogas dari kotoran sapi sebenarnya sudah dikembangkan secara masif di pulau Jawa. Di tahun 2010 telah dibangun 1.300 reaktor biogas (biodigester) tingkat rumah tangga bagi peternak sapi perah yang dilanjutkan dengan 8.000 unit di tahun 2012 (4). Berbeda dengan di Pulau Jawa, di Kali-mantan Selatan jumlah peternak sapi jauh lebih sedikit dibandingkan peternak ayam. Populasi ayam yang dikembangkan di sektor peternakan di Kalimantan Selatan di tahun 2010 saja telah mencapai 48 juta ekor (5).

Dibandingkan kotoran sapi, kotoran ayam memiliki kandungan air dan rasio $\mathrm{CN}$ yang lebih rendah sehingga lebih sulit diolah dan dapat menimbulkan bau yang menyengat (6). Kotoran ayam juga lebih banyak menghasilkan amoniak sehingga sebaran bau yang dihasilkan dapat mencapai ribuan meter dari kandang ternak (7).

Menurut Prasetyo (2009), kotoran ayam dapat diolah menjadi biogas selama rasio $\mathrm{CN}$ dan faktor pendukungnya terpenuhi (8). Unsur $\mathrm{N}$ yang banyak terdapat dalam kotoran ayam merupakan makanan bakteri metanogen sehingga potensinya untuk menghasilkan biogas lebih besar. Rasio CN sendiri bisa ditingkatkan dengan penambahan bahan organik yang memiliki rasio $\mathrm{CN}$ lebih tinggi seperti batang jagung, jerami, serbuk gergaji dan sebagainya (9).
Kelebihan unsur $\mathrm{N}$ dapat dioptimalkan melalui pemecahan protein dengan bantuan enzim papain yang terdapat dalam getah pepaya. Papain adalah enzim proteolitik yang mengkatalisa reaksi pemecahan rantai poli-peptida pada protein dengan cara menghidrolisa ikatan peptide-nya menjadi senyawa yang lebih sederhana seperti dipeptida dan asam amino (10). Senyawa sederhana inilah yang menjadi suplai makanan untuk bakteri metanogen pembentuk methan yang terdapat dalam biogas.

Berdasarkan latar belakang di atas peneliti tertarik melakukan percobaan pembuatan biogas dari kotoran ayam dan kotoran sapi dengan bantuan enzim papain dengan tujuan 1) mengetahui potensi biogas dari kotoran sapi dan kotoran ayam, 2) mengetahui pengaruh penambahan enzim papain terhadap percepatan produksi biogas.

\section{BAHAN DAN CARA PERCOBAAN}

Biogas dibuat dari campuran bahan baku, bahan pencampur, bahan pengencer dan katalis. Bahan baku adalah kotoran sapi atau kotoran ayam, sedangkan bahan pencampur adalah bahan lain yang ditambahkan untuk mengatur rasio $\mathrm{CN}$ pada kisaran 25 s.d. 30. Bahan pencampur yang digunakan dalam percobaan ini adalah sekam. Kotoran sapi, kotoran ayam dan sekam masing-masing memiliki rasio $\mathrm{CN}$ sebesar 24, 10 dan 70. Dengan demikian rasio campuran sekam dengan kotoran ayam antara 1 : 2 hingga $1: 3$, sedangkan untuk kotoran sapi $1: 7$ (9). Bahan pengencer adalah air bersih yang ditambahkan dalam campuran bahan. Rasio campuran air optimal untuk kotoran sapi adalah 0,79:1 (11), sedangkan rasio campuran air untuk kotoran ayam adalah 1 : 1 . Hal ini disebabkan kotoran ayam memiliki kandungan bahan kering 1,39 kali lebih tinggi daripada kotoran sapi. Katalis adalah bahan tambahan yang digunakan untuk mempercepat reaksi pemecahan bahan organik. Katalis yang digunakan adalah enzim papain yang diwakili oleh potongan buah papaya mentah $2 \mathrm{~kg}$ dan 4 $\mathrm{kg}$.

Biogas diproduksi dalam sebuah tabung tertutup yang disebut digester. Setiap digester dibuat dari dua buah drum plastik berkapasitas $0,2 \mathrm{~m}^{3}$ dan $0,18 \mathrm{~m}^{3}$ masing- 
masing untuk penampung bahan baku dan penampung gas, pipa PVC dan sambungan- sambungannya, serta sebuah keran besi untuk pengeluaran gas (Gambar 1).
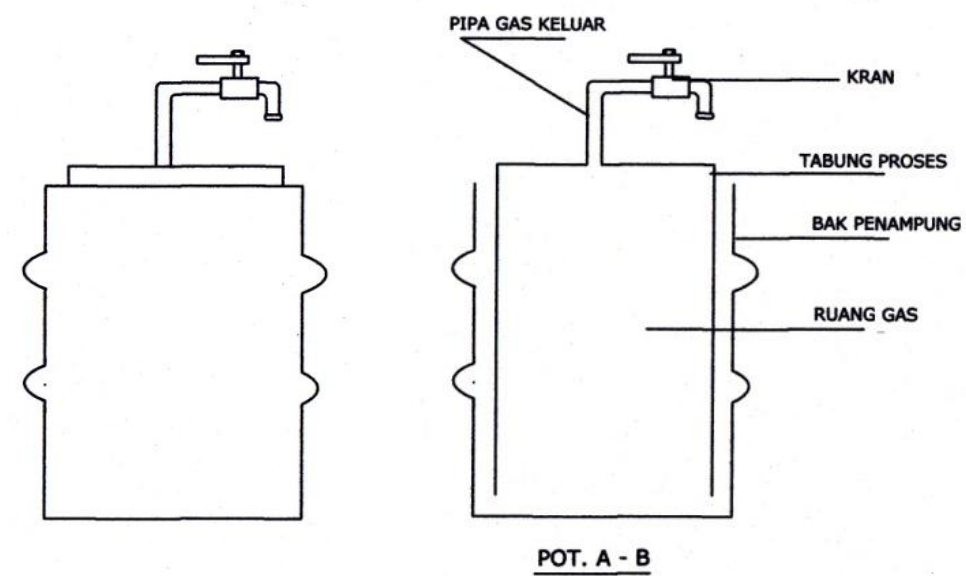

Gambar 1. Digester biogas

Instrumen lain yang dibutuhkan dalam observasi adalah timbangan untuk mengukur massa bahan, meteran untuk mengukur volume produksi biogas, alat pengukur waktu, termometer dan $\mathrm{pH}$ meter.

Percobaan diawali dengan pengolahan bahan campuran, meliputi kegiatan penimbangan, homogenisasi, dan pengadukan sampai seluruh bahan siap dieramkan dalam digester. Massa kotoran sapi dan kotoran ayam ditetapkan sebesar $75 \mathrm{~kg}$ kemudian sebagai variasi perlakuan ditambahkan katalis yang direpresentasikan dengan $0 \mathrm{~kg}, 2 \mathrm{~kg}$ dan $4 \mathrm{~kg}$ potongan buah pepaya mentah. Setiap variasi diujicobakan sebanyak 3 kali sebagai ulangan sehingga total perlakuan dalam percobaan ini adalah 2 bahan baku x 3 variasi katalis x 3 kali ulangan = 18 sampel. Selanjutnya dilakukan pengamatan, uji coba pembakaran dan pencatatan (waktu, $\mathrm{pH}$, temperatur dan volume produksi) setiap hari pada jam yang sama. Percobaan ini seluruhnya dilaksanakan di bengkel kerja Poltekkes Kemenkes Banjarmasin Jurusan Kesehatan Lingkungan Banjarbaru. Dengan rancangan quasy experiment pengamatan dilakukan selama 90 hari, terdiri dari 3 kali pengamatan x 30 hari perpengamatan.

\section{HASIL PERCOBAAN DAN PEMBAHASAN Produksi Biogas}

Pengamatan terhadap produksi biogas telah dilaksanakan selama 90 hari namun hanya data pengamatan terakhir yang dianalisis. Hal ini disebabkan beberapa masalah yang penyebabnya diketahui setelah pengamatan berjalan, antara lain:

1. Kotoran ayam belum berhasil diolah menjadi biogas.

2. Penambahan sekam untuk meningkatkan unsur $\mathrm{C}$ dalam campuran bahan belum efektif.

3. Volume produksi biogas dari kotoran sapi sangat berfluktuasi dan tidak liner dengan penambahan enzim papain.

4. Penambahan air dengan rasio 1:1 masih terlalu pekat.

Dalam dua kali pengamatan awal, kotoran ayam tidak menghasilkan biogas meskipun gas yang dihasilkan lebih cepat dan lebih banyak dibandingkan kotoran sapi. Gas yang keluar dari ujung keran berbau menyengat yang diduga disebabkan oleh amoniak sehingga tidak menyala saat dibakar. Karena kondisi ini, pengamatan produksi biogas dari kotoran ayam tidak dilanjutkan.

Rasio CN yang rendah pada kotoran ayam menunjukkan kelebihan unsur $\mathrm{N}$ dan kekurangan unsur C. Sekam yang ditambahkan untuk menyuplai kekurangan unsur $\mathrm{C}$ ternyata tidak efektif karena faktor dekomposisinya yang sangat lambat. Hal ini berbeda dengan kotoran ayam yang terdekomposisi sejak dimasukkan ke dalam digester dengan indikasi meningkatnya temperatur pada digester dan terbentuknya gelembung-gelembung gas di permukaan slurry. Dalam dua hari, drum penampung terisi penuh oleh gas hasil dekomposisi 
kotoran ayam, sedangkan butiran sekam hampir tidak berubah hingga akhir waktu pengamatan. Gas nitrogen yang dibebaskan selama proses dekomposisi berakumulasi membentuk ammonia $\left(\mathrm{NH}_{4}\right)$ dan meningkatkan pH antara 8 hingga 8,5. Kondisi ini berpotensi mematikan populasi bakteri metanogen pembentuk gas methan. Hal ini sejalan dengan hasil penelitian Haryati (2006), (9).

Volume produksi biogas dari kotoran sapi yang sangat berfluktuasi dan tidak berkorelasi dengan penambahan enzim papain diduga disebabkan oleh ketidakseragaman bahan baku. Perbedaan spesies sapi, makanan dan lamanya kotoran berada di lingkungan menyebabkan komposisi kotoran terutama kandungan bahan kering dan rasio $\mathrm{CN}$ bervariasi satu sama lain. Penambahan sekam pada kotoran sapi juga tidak efektif karena di samping dekomposisinya yang sangat lambat, keberadaanya juga

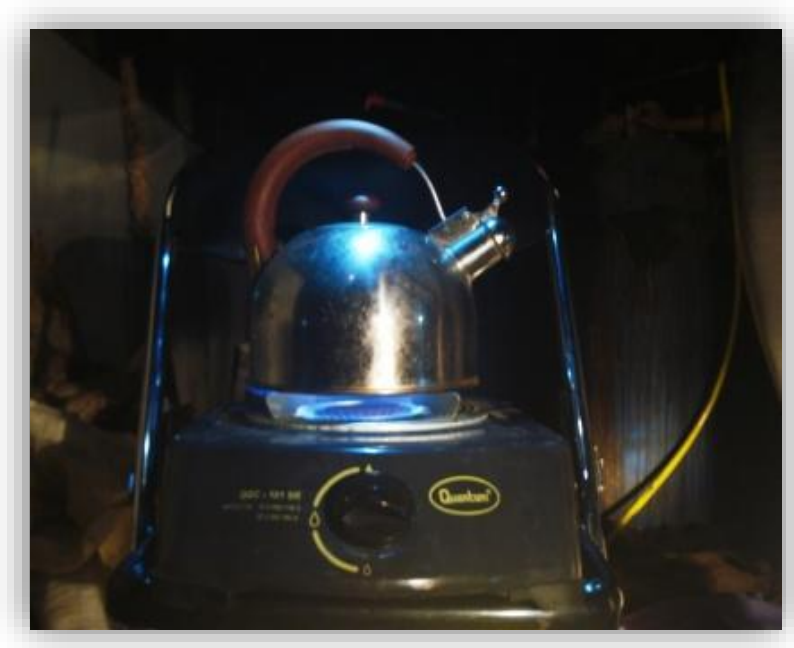

menghambat pergerakan drum penampung gas methan. Penambahan air dengan rasio 1:1 juga dinilai masih terlalu pekat sehingga menghambat keleluasaan pergerakan drum penutup dan menyebabkan banyak bahan baku di bagian atas drum penampung terbuang. Dalam percobaan ini ditemukan rasio optimal antara air dengan bahan baku sebesar $1 \frac{1}{2}: 1$. Beberapa kondisi di atas menyebabkan data pengamatan yang dapat digunakan hanya data pengamatan terakhir (30 hari) dimana bahan baku yang digunakan hanya kotoran sapi dan tanpa penambahan sekam.

Biogas dari kotoran sapi sebenarnya sudah diproduksi dalam 24 jam pertama yang dibuktikan dengan nyala api di ujung keran digester dan kompor gas (Gambar 2). Namun untuk meminimalisir gangguan gasgas lain, pencatatan produksi biogas dimulai pada hari ke-3 setelah seluruh isi drum penampung dikosongkan.

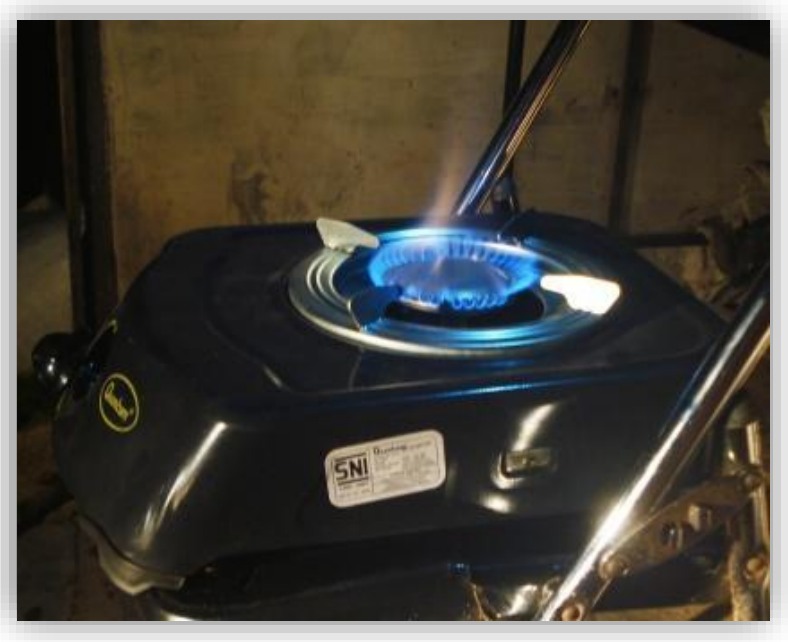

Gambar 2. Uji coba biogas pada kompor gas

Kotoran sapi cepat menghasilkan biogas karena pada dasarnya, fermentasi anaerobik telah terjadi dalam sistem pencernaan sapi dengan adanya bakteri Methanosarcina sp. (12). Dengan demikian selulosa yang terdapat dalam kotoran sapi sudah merupakan bahan "setengah matang" yang mudah diuraikan. Di sisi lain kotoran sapi mengandung selulosa dengan rasio $\mathrm{CN}$ optimal, sehingga untuk menghasilkan biogas tidak membutuhkan campuran bahan lain.

Enzim papain terlihat memberikan efek percepatan produksi biogas di minggu pertama pengamatan (Gambar 3). Setelah itu produksi berlangsung normal mengikuti pola produksi biogas dari kotoran murni. Rata-rata produksi biogas pada ketiga digester hampir sama yaitu antara 30-34 liter perhari atau 1,3-1,45 $\mathrm{m}^{3}$ perbulan.

\section{Pengaruh penambahan enzim papain}

Kamase (2009), dalam situsnya menyatakan bahwa biogas dari kotoran sapi terbentuk pada hari ke 4-5 dan mencapai puncak pada hari ke 20-25 (13). Pernyataan tersebut terlihat relevan dengan produksi biogas dari kotoran sapi murni (Gambar 3). 


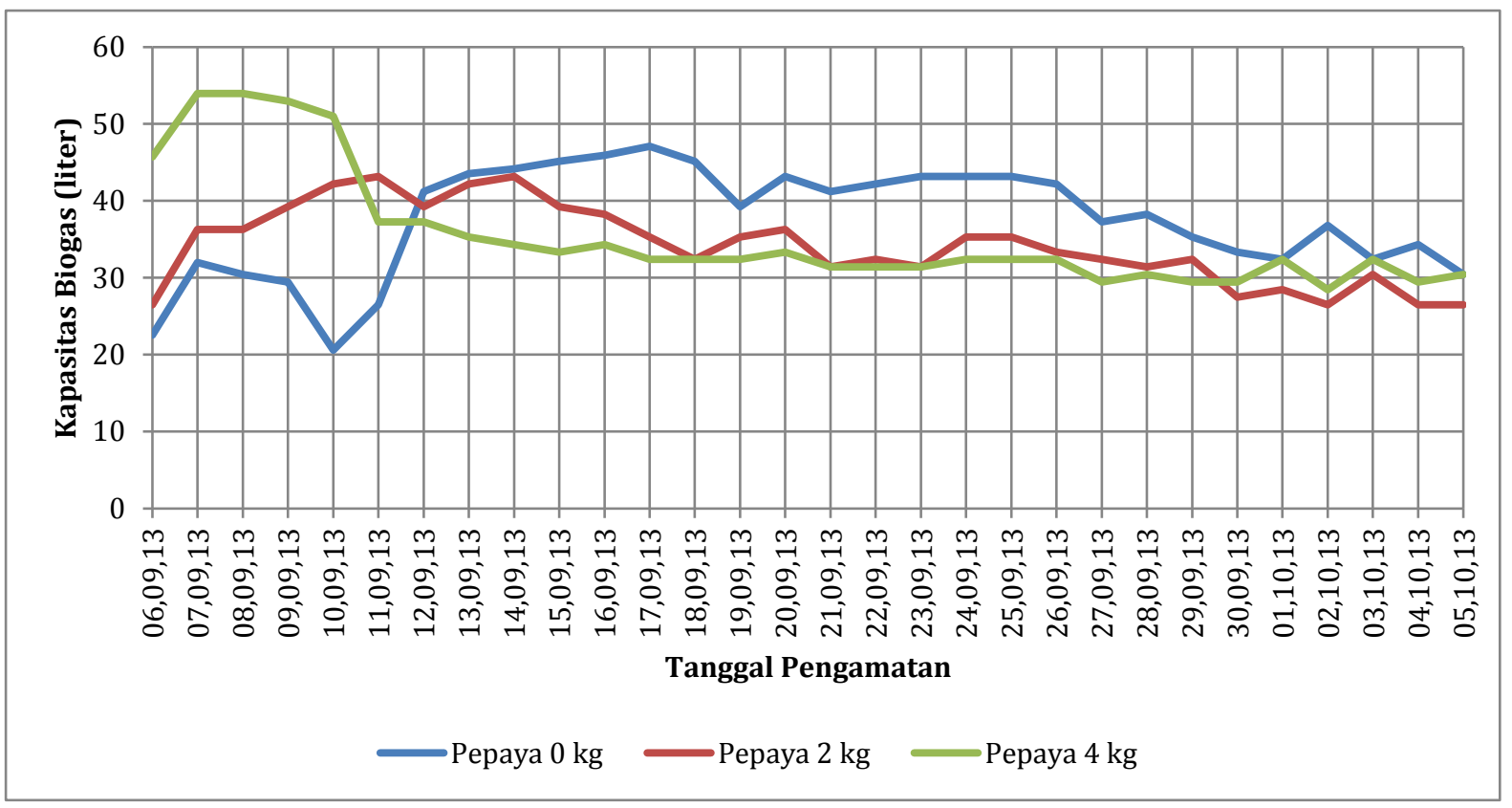

Gambar 3. Perbandingan produksi biogas dari kotoran sapi dengan variasi penambahan potongan buah pepaya mentah $0 \mathrm{~kg}, 2 \mathrm{~kg}$, dan $4 \mathrm{~kg}$.

Pada kotoran sapi yang ditambahkan enzim papain, produksi biogas meningkat sejak dieramkan dan mencapai puncak pada minggu pertama. Semakin banyak tambahan buah pepaya terlihat laju produksi biogas juga semakin tinggi. Gambar 4 menunjukkan produksi biogas dalam satu minggu, dari kotoran sapi murni hanya 202,7 liter, sedangkan dengan penambahan potongan pepaya $2 \mathrm{~kg}$ sebesar 263 liter atau 1,3 kali lebih banyak dan dengan penambahan potongan pepaya $4 \mathrm{~kg}$ sebesar 332,3 liter atau 1,6 kali lebih banyak.

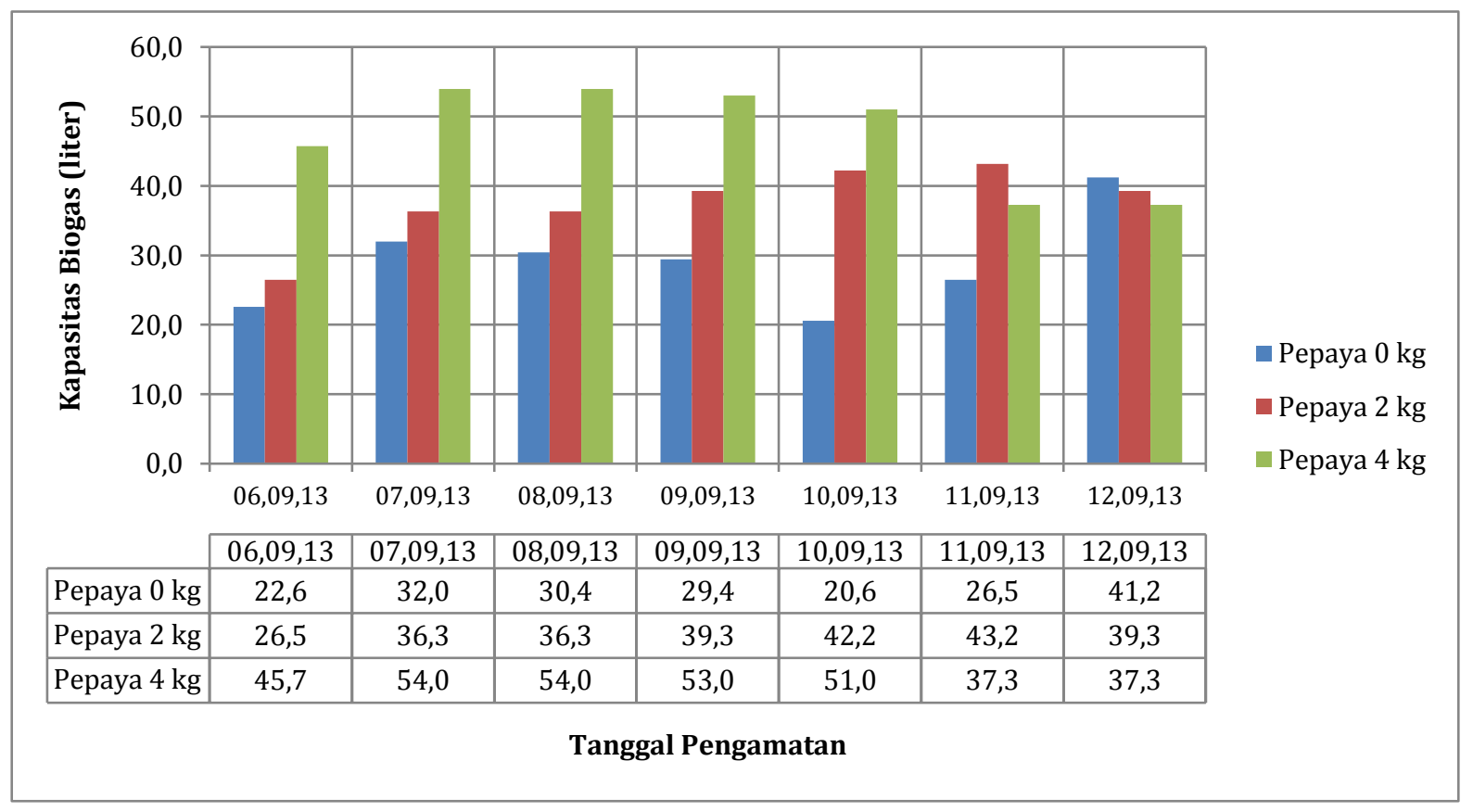

Gambar 4. Perbandingan produksi biogas dari kotoran sapi selama satu minggu dengan variasi penambahan potongan buah pepaya mentah $0 \mathrm{~kg}, 2 \mathrm{~kg}$, dan $4 \mathrm{~kg}$. 
Selulosa "setengah matang" yang terdapat dalam kotoran sapi mempermudah kerja enzim papain. Saat sebagian selulosa terhidrolisis menjadi glukosa, waktu yang dibutuhkan untuk membentuk asam lemak dan alkohol (senyawa dasar pembentuk gas methan) menjadi lebih singkat. Dipeptida dan asam amino yang terbentuk dari hasil kerja enzim papain inilah yang memberikan suplai energi yang lebih banyak untuk aktifitas bakteri metanogen.

Percepatan produksi biogas memberikan banyak keuntungan. Di samping potensi eksploitasi biogas yang lebih besar, kotoran sapi dapat diproses lebih cepat sehingga tidak menumpuk dan mencemari lingkungan. Ampas sisa pengolahan biogas merupakan pupuk organik yang kaya unsur hara dan bernilai ekonomis lebih tinggi dibandingkan kotoran sapi. Percepatan siklus produksi biogas dengan sendirinya juga mempercepat produksi pupuk organik ini.

\section{Kelemahan Percobaan}

Meskipun produksi biogas dari kotoran sapi dengan penambahan enzim papain berhasil dilakukan namun masih terdapat beberapa kelemahan yang dapat dijadikan pertimbangan dan dasar perbaikan untuk percobaan selanjutnya, antara lain: 1) Komposisi campuran mengikuti referensi penelitian sebelumnya tidak sesuai dengan kondisi di lapangan dan homogenitas bahan yang tidak dikendalikan di awal percobaan menghabiskan banyak waktu percobaan. Hal ini menyebabkan sisa waktu yang digunakan untuk pengamatan tidak cukup untuk pengulangan. 2) Percobaan tidak diawalai dengan analisis kandungan bahan (trace element) baik untuk bahan baku maupun hasil percobaan. Analisis kandungan bahan baku sangat dibutuhkan untuk menentukan rasio $\mathrm{CN}$ sehingga dapat ditentukan perlu tidaknya penambahan bahan pencampur. Selain itu analisis prosentase bahan kering juga dibutuhkan untuk menentukan volume campuran air. Analisis kandungan biogas juga dibutuhkan untuk menentukan secara pasti kapan komposisi ideal biogas yang terdiri dari $60 \%$ gas $\mathrm{CH}_{4}, 38 \% \mathrm{CO}_{2}$ dan $2 \%$ kandungan lain mulai terbentuk. Informasi ini dibutuhkan untuk memastikan titik awal pengamatan. 3) Enzim papain direpresentasikan oleh potongan buah papaya mentah sehingga tidak menjelaskan kebutuhan enzim secara akurat untuk dekomposisi sejumlah bahan baku. 4) Tidak tersedia bahan organik lain dengan laju dekomposisi yang lebih baik untuk menggantikan sekam, sehingga produksi biogas menggunakan kotoran ayam tidak bisa dilanjutkan.

\section{KESIMPULAN DAN SARAN}

Kotoran ayam secara mandiri tidak dapat diolah menjadi biogas sehingga dibutuhkan campuran bahan organik lain yang memiliki rasio $\mathrm{CN}$ lebih tinggi dan mudah terurai. Kotoran sapi dapat diolah menjadi biogas tanpa campuran bahan organik lain dan dapat dipercepat produksinya dengan penambahan enzim papain. Kapasitas produksi biogas dari kotoran sapi dengan bahan baku $75 \mathrm{~kg}$ berkisar antara 1,3 hingga $1,45 \mathrm{~m}^{3}$. Penambahan enzim papain dalam potongan buah pepaya mentah terbukti mempercepat produksi biogas antara 1,3 kali (untuk $2 \mathrm{~kg}$ buah pepaya) hingga 1,6 kali (untuk $4 \mathrm{~kg}$ buah pepaya) dalam satu minggu pertama pengamatan. Rasio optimal antara bahan pengencer dan kotoran sapi adalah $1 \frac{1}{2}: 1$.

Pengolahan biogas berbahan dasar kotoran ayam dapat dilanjutkan dengan mempertimbangkan alternatif bahan pencampur lain yang memiliki rasio $\mathrm{CN}$ di atas 30 dan mudah terurai. Jika bahan pencampur yang digunakan adalah sekam, sebaiknya dihaluskan dan dibusukkan terlebih dahulu dalam wadah terpisah untuk mempercepat penguraian. Untuk menunjang pengolahan biogas secara lebih optimal dibutuhkan analisis kandungan bahan terlebih dahulu karena referensi tentang rasio $\mathrm{CN}$ berbagai bahan masih sangat minim dan bervariasi. Percobaan biogas menggunakan enzim papain murni perlu dilakukan untuk menemukan kuantitas campuran enzim secara tepat.

\section{KEPUSTAKAAN}

1. Anonymous. Greenhouse Gases Emission. epa.gov. [Online] US EPA, 8 31, 2012. [Cited: 11 7, 2012.] http://www.epa.gov/climatechange/gh gemissions/gases.html.

2. - Biogas FAQ. electrigez. [Online] 2012. [Cited: 11 7, 2012.] http://www.electrigaz.com/faq_en.htm. 
3. Fahruddin, Ali. Program Konversi Minyak Tanah ke Gas Elpiji 3 Kg Masih Menyisakan Masalah. Tanjabtimkab. [Online] 11 7, 2011. [Cited: 11 7, 2012.] http://www.tanjabtimkab.go.id/v2/ind ex.hp?option=com_content\&view=articl e\&id=60: program-program-konversiminyak-tanah-ke-gas-elpiji-3kg-masihmenyisakanmasalah\&catid=48:artikel\&itemid=67.

4. Eki. 1.300 Reaktor Biogas Rumah Dibangun di Jawa. Kompas. [Online] 4 15, 2010. [Cited: 12 1, 2012.] http://regional.kompas.com/read/201 0/04/15/21261374/1.300.Reaktor.Bio gas.Rumah.Dibangun.di.Jawa.

5. Anonymous. Kondisi yang Ingin Dicapai. Dinas Peternakan Prov. Kalsel. [Online] 1 18, 2011. [Cited: 11 7, 2012.] http://disnak.kalselprov.go.id/index.ph p?option=com_content\&view $=$ article\&i d=6:kondisi-yang-ingin-dicapai-.

6. Biogas. Kaltwasser, Bernd. 1980, Wiesbaden, pp. 35-56.

7. Adnan S., Kunta. Mengapa Terjadi Bau Busuk pada Peternakan Ayam? Fedco Sierra. [Online] 10 4, 2009. [Cited: 12 1, 2012.]

http://www.fedcosierra.com/2010/05/ mengapa-terjadi-bau-busuk-pada.html.

8. Prasetyo, Didit Eko. Produksi Biogas pada Fermentasi Ekskreta Ayam Broiler Menggunakan Starter Bakteri Fibrolitik Kolon Domba. Universitas Muhammadiyah Malang, Fakultas Peternakan dan Perikanan. Malang : UNM, 2009. Skripsi.

9. Biogas: Limbah Peternakan yang Menjadi Sumber Energi Alternatif. Haryati,
Tuti. 2006, Wartazoa, Vol. Vol. 16 No.3, p. 163.

10. Winarno, F. G. Kimia Pangan dan Gizi. Jakarta: PT. Gramedia Pustaka Utama, 2002.

11. Pengaruh Perbandingan Kandungan Air dengan Kotoran Sapi terhadap Produktifitas Biogas pada Digester Bersekat. Triyatno, Joko. 2012, Media Sains, p. 165. 2085-3548.

12. Fithry, Y. Pengaruh Penambahan Cairan Rumen Sapi pada Pembentukan Biogas dari Sampah Buah Mangga dan Semangka. Universitas Gajah Mada, Program Pascasarjana. Yogyakarta : s.n., 2010. Tesis .

13. Care, Kamase. Cara Mudah Membuat Digester Biogas. Kamase. [Online] 6 6, 2009. [Cited: 6 6, 2014.] http://www.kamase.org/?p=548.

14. Simamora, Suhut, et al. Membuat Biogas Pengganti Bahan Bakar Minyak Dan Gas Dari Kotoran Ternak. Jakarta: PT AgroMedia Perkasa, 2006.

15. Paimin, Farry B. Alat Pembuat Biogas dari Drum. Jakarta: Penebar Swadaya, 2001.

16. Said, Sjahruddin. Membuat Biogas Dari Kotoran Hewan. Jakarta : Bentara Cipta Prima, 2008.

17. Pemanfaatan Enzim Papain Sebagai Penggumpal Susu dalam Pembuatan Keju. Yuniwati, Murni, Yusran and Rahmadany. Yogyakarta: Seminar Nasional Aplikasi Sains dan Teknologi 2008-IST AKPRIND Yogyakarta, 2008. 